\title{
Effects of storage on the estimates of virus- mediated bacterial mortality based on observation of preserved seawater samples with TEM
}

\author{
Chung Yeon Hwang, Byung Cheol Cho*
}

\begin{abstract}
Molecular and Microbial Ecology Laboratory, School of Earth and Environmental Sciences and Research Institute of Oceanography, Seoul National University, Seoul 151-742, Republic of Korea
\end{abstract}

\begin{abstract}
There are reports in the literature that the long-term storage (e.g. >30 d) of fixativepreserved seawater samples causes significant decreases in bacterial (BA) and viral abundances (VA). However, the effects of storage on the frequency of visibly infected bacteria (FVIB), and consequently on bacterial mortality due to viral lysis (BMVL), remain to be evaluated. First, to determine

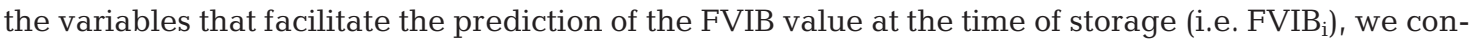
sidered a bacterial community composed of 2 groups (i.e. visibly infected bacteria and the others) and assumed an exponential decay relationship for the bacteria in each group during the storage of preserved samples. In the hypothetical model, the $\mathrm{FVIB}_{\mathrm{i}}$ could be well estimated in terms of BA at the time of storage, a decay rate of $\mathrm{BA}$, and $\mathrm{FVIB}_{\mathrm{f}}$ and $\mathrm{BA}_{\mathrm{f}}$ (i.e. FVIB and BA measured at the end of storage, respectively). Further, we tested this idea by applying it to 7 seawater samples that were preserved with $2 \%$ glutaraldehyde (final conc.) and stored at different temperatures for ca. $30 \mathrm{~d}$. For the 3 preserved coastal samples, considerably better estimates of BMVL were obtained by applying the theoretical consideration to estimate the $\mathrm{FVIB}_{\mathrm{i}}$ (the BMVL was estimated to be 89.9 to $118.7 \%$ of the BMVL at the time of storage $\left[B M V L=1\right.$, which was the value calculated with $\mathrm{FVIB}_{\mathrm{i}}$ ) than if $\mathrm{FVIB}_{\mathrm{f}}$ was used (the BMVL was estimated to be 45.5 to $89.9 \%$ of the $\mathrm{BMVL}_{\mathrm{i}}$ value). Interestingly, estimates of the BMVL obtained for the 4 preserved offshore samples were comparable to the FVIB values measured at 3 to $5 \mathrm{~d}$ after the start of the experiments, as in the case of preserved coastal samples in the present study, suggesting that it may be possible to estimate FVIB $_{\mathrm{i}}$ values for preserved offshore samples. It is recommended that the above-mentioned variables be measured in order to reliably estimate the FVIB value at the time of preservation for fixative-amended and frozen seawater samples that may be stored for a long time, such as oceanic cruises.
\end{abstract}

KEY WORDS: Preservation · Bacteria · Viruses · Bacterial mortality · Viral lysis · Transmission electron microscopy $\cdot$ TEM

\section{INTRODUCTION}

Ecological studies on the distributions and interactions of microbes (e.g. bacteria and viruses) have been performed in various marine environments, ranging from coastal to open oceans (Wommack \& Colwell 2000, Choi et al. 2003, Weinbauer 2004). In many instances, it becomes necessary to preserve seawater samples in the field and transport them to a land-based laboratory for further analyses. In cases such as oceanic cruises, a preservation period of longer than a couple of weeks is unavoidable. A number of studies have shown the effects of long-term storage on the bacterial (BA) and viral abundance (VA) in preserved samples; the BA and VA in samples have been reported to significantly decrease with long-term storage 
(e.g. $1 \mathrm{mo}$ ), despite immediate preservation of the samples with various fixatives (e.g. formalin or glutaraldehyde) and storage at low temperatures (e.g. -20 or $4^{\circ} \mathrm{C}$ ) after sampling (Turley \& Hughes 1992, 1994, Brussaard 2004, Wen et al. 2004). The decreases in the BA in preserved seawater samples were considered to be probably due to the attachment of the cells to the inner surface of the storage bottle (Turley \& Hughes 1992) and continuous enzymatic breakdown activity in the glutaraldehyde-preserved seawater (Gundersen et al. 1996). Similar processes may influence the decrease in the VA in preserved seawater samples (Suttle \& Chen 1992, Noble \& Fuhrman 1997).

However, there is no study on the effects of longterm storage on the frequency of visibly infected bacteria (FVIB), which is critical for estimating bacterial mortality due to viral lysis (BMVL). For FVIB determination using transmission electron microscopy (TEM), seawater samples are routinely preserved with glutaraldehyde and then stored at $4^{\circ} \mathrm{C}$ until the sample is ultracentrifuged on a TEM grid in a land-based laboratory. During oceanic cruises, the long-term storage of preservative-amended samples for TEM observation is unavoidable (Steward et al. 1996) because an ultracentrifuge cannot be operated on unstable surfaces, such as on board a floating ship, since the instability can cause the rotors to break loose while spinning, leading to damage of the ultracentrifuge (Rotor Safety Guide, Beckman Coulter, www.beckmancoulter.com). The FVIB might be expected to change during the storage period, similar to the BA and VA in preserved seawater samples (Turley \& Hughes 1992, 1994, Brussaard 2004), probably due to the different decay rates of non-nucleoid-containing cells (ghost cells), virusinfected cells, and intact (healthy) cells. Since the FVIB is directly used to estimate the effect of viruses on bacterial mortality (Binder 1999), using the FVIB of longterm stored samples might lead to errors in such estimates if the FVIB at the time of preservation changed significantly with storage. In the present study, theoretical considerations were made in order to estimate the FVIB at the time of preservation for the samples that were stored for a long time, and these considerations were applied to field samples.

\section{MATERIALS AND METHODS}

Sample collections. Three coastal water samples were collected from the surface water of an east coastal site $\left(37^{\circ} 54^{\prime} \mathrm{N}, 128^{\circ} 49^{\prime} \mathrm{E}\right)$ on both January 24 , 2005 (Stn JJ), and August 9, 2007 (Stn JA), and that of a west coastal site $\left(37^{\circ} 19^{\prime} \mathrm{N}, 126^{\circ} 37^{\prime} \mathrm{E}\right)$ on August 16 , 2007 (Stn S). Four offshore samples were collected from the East Sea, Korea, between June 16 and 18,
2004; the 2 sampling stations (Stn B1: $37^{\circ} 00^{\prime} \mathrm{N}$, $129^{\circ} 41^{\prime} \mathrm{E}_{\text {; }} \mathrm{Stn} \mathrm{B} 2 \mathrm{:} 36^{\circ} 30^{\prime} \mathrm{N}, 131^{\circ} 00^{\prime} \mathrm{E}$ ) were ca. 35 and $140 \mathrm{~km}$ off the east coast of Korea, at depths of about 210 and $2000 \mathrm{~m}$, respectively. Water samples were obtained from 5 and $170 \mathrm{~m}$ below the surface of Stn B1 and 5 and $500 \mathrm{~m}$ below the surface of Stn B2, using 101 Niskin bottles mounted on a conductivity-temperature-depth profiler (CTD; SBE 911plus, Sea-Bird Electronics) rosette. The samples were immediately transferred to acid-washed 51 polyethylene (PE) bottles (Nalgene).

Sample storage. For the coastal samples, storage experiments were conducted twice at 3 different temperatures $\left(4,-20\right.$, and $\left.-80^{\circ} \mathrm{C}\right)$. The coastal samples from Stns JA and $\mathrm{S}$ were kept in ice and transported to a land-based laboratory within 2 to $5 \mathrm{~h}$ of collection. For storage at $4^{\circ} \mathrm{C}$, the seawater samples were transferred to $500 \mathrm{ml} \mathrm{PE}$ bottles (Nalgene) in triplicate, and the sample in each bottle was immediately preserved with $70 \%$ electron microscopy-grade glutaraldehyde (Sigma; final conc. of $2 \%$ ) and then stored at $4{ }^{\circ} \mathrm{C}$ in the dark. Subsamples were obtained during the timecourse experiment and processed as described below. For storage at $-20^{\circ} \mathrm{C}$, the seawater samples were transferred to a $11 \mathrm{PE}$ bottle (Nalgene) and preserved with the same fixative as mentioned above. Aliquots were dispensed into thirty $15 \mathrm{ml}$ sterile polypropylene centrifuge tubes (Corning Costar). The subsamples were then frozen and preserved at $-20^{\circ} \mathrm{C}$ in the dark until analyses. Finally, for storage at $-80^{\circ} \mathrm{C}$, the seawater samples were treated in the same way as in the $-20^{\circ} \mathrm{C}$ storage experiment, except that the dispensed samples were flash frozen in liquid nitrogen and subsequently stored at $-80^{\circ} \mathrm{C}$ in the dark until analyses. During the latter 2 storage experiments, 3 tubes were randomly selected and thawed with cold tap water and processed as described below. For the offshore seawater samples and a sample from Stn JJ, storage experiments were performed in duplicate at 2 temperatures (4 and $-20^{\circ} \mathrm{C}$ ).

Bacterial and viral abundance. The coastal samples were prepared for BA and VA counts within $2 \mathrm{~h}$ after they were brought to the land-based laboratory; the samples were prepared as described below. The BA and VA counts of the offshore samples had to be performed on land because the research vessel was not equipped with an epifluorescence microscope. Turley \& Hughes (1992) reported that there was no significant difference between the BA counts carried out at sea and those obtained for the same stained, filtered samples that were stored, frozen, and recounted on land. In addition, Wen et al. (2004) found that accurate estimates of the VA could be made with aldehyde-fixed samples if slides were prepared immediately and stored at $-20^{\circ} \mathrm{C}$ for $2 \mathrm{wk}$. Thus, on board the ship, the 
offshore samples for the first 2 time points ( 3 to $5 \mathrm{~d}$ of storage) in the storage experiments were filtered using $0.02 \mu \mathrm{m}$ pore size Anodisc filters (Whatman). The filters were then laid on a $100 \mu \mathrm{l}$ drop of diluted SYBR Green I (final dilution, $2.5 \times 10^{3}$-fold; Noble \& Fuhrman 1998) for $15 \mathrm{~min}$ in the dark, mounted on microscope slides, and frozen at $-20^{\circ} \mathrm{C}$. The BA and VA of the slides were counted at the land-based laboratory (ca. 3 to $5 \mathrm{~d}$ after each experiment began). Further, the BA and VA counts of the offshore samples stored for 1 mo were performed. The BA and VA were determined by using a blue filter set on an epifluorescence microscope (BX60, Olympus) at 1250×. The initial BA and VA counts for the coastal samples from Stns JJ, JA, and S were $1.1 \times 10^{6}$ and $2.2 \times 10^{7} \mathrm{ml}^{-1}, 0.4 \times 10^{6}$ and $1.3 \times$ $10^{7} \mathrm{ml}^{-1}$, and $3.0 \times 10^{6}$ and $6.0 \times 10^{7} \mathrm{ml}^{-1}$, respectively. The initial BA and VA counts for offshore samples from Stns B1 (collected at a depth of $5 \mathrm{~m})$, B1 $(170 \mathrm{~m})$, B2 $(5 \mathrm{~m})$, and B2 $(500 \mathrm{~m})$ were $0.9 \times 10^{6}$ and $2.1 \times 10^{7} \mathrm{ml}^{-1}$, $0.6 \times 10^{6}$ and $0.9 \times 10^{7} \mathrm{ml}^{-1}, 0.9 \times 10^{6}$ and $0.8 \times 10^{7} \mathrm{ml}^{-1}$, and $0.3 \times 10^{6}$ and $0.3 \times 10^{7} \mathrm{ml}^{-1}$, respectively.

FVIB and BMVL. The preparation for TEM observation of visibly virus-infected bacteria was performed at a land-based laboratory. The bacteria were harvested directly onto Formvar-coated, 200-mesh, electron microscope grids within 2 to $7 \mathrm{~h}$ of subsampling. For the offshore seawater samples, the first time point for preparing the TEM grids for FVIB measurements was 3 to $5 \mathrm{~d}$ after the start of the storage experiments. The grids were made uniformly hydrophilic by floating them on a drop of $1 \%$ poly-L-lysine (Sigma) for $1 \mathrm{~min}$ prior to use (Suttle 1993). Nine $\mathrm{ml}$ of the preserved coastal and offshore surface samples (collected at depths of 0 to $5 \mathrm{~m}$ ) that were stored at $4{ }^{\circ} \mathrm{C},-20^{\circ} \mathrm{C}$ (i.e. thawed samples), and $-80^{\circ} \mathrm{C}$ (i.e. thawed samples) were centrifuged (XL-90, Beckman) at $30000 \times g$ using a swinging bucket rotor (SW41, Beckman) for $30 \mathrm{~min}$ at $20^{\circ} \mathrm{C}$. To acquire an adequate amount of bacteria for enumeration from the preserved deeper seawater samples (collected at depths of 170 to $500 \mathrm{~m}), 9 \mathrm{ml}$ of the samples were centrifuged, and the supernatant was carefully discarded. Then, the same preserved samples were refilled and centrifuged again. This procedure was repeated 2 to 4 times (i.e. 18 to $36 \mathrm{ml}$ of each sample was centrifuged on a grid). The grids were stained for $20 \mathrm{~s}$ with $0.5 \%$ uranyl acetate (Sigma), followed by 3 sequential rinses with $0.02 \mu \mathrm{m}$-filtered Milli- $\mathrm{Q}^{\circledR}$ water. The virus-infected bacteria were enumerated using a JEOL JEM-1010 TEM or a JEOL 2000 EXII TEM at an accelerating voltage of $80 \mathrm{keV}$ (Weinbauer et al. 1993). For each sample, 400 to 700 cells were examined using a TEM at magnification ranging from $30000 \times$ to $50000 \times$. Cells were scored as infected if they contained 5 or more intracellular virus-like particles (VLP). The num- bers of visibly infected bacteria were $18 \pm 8$ (mean \pm SD) cells sample ${ }^{-1}$. Burst size was estimated as the average number of VLP observed in all visibly infected bacteria. The frequency of infected bacteria (FIB) was estimated from the FVIB using the average conversion factor of 7.11 that has been established for natural communities (Hwang \& Cho 2002, Weinbauer et al. 2002). The BMVL was estimated from the FIB using a model that assumed that the infected and uninfected cells are grazed at the same rate and that the latent period is equal to the generation time of the bacteria (Binder 1999).

Statistics. The data of BA, VA, and visibly infected bacterial abundance (VIBA, a product of the BA and FVIB for a given sample) for each storage temperature were plotted against storage time and best fitted with an exponential model (Turley \& Hughes 1992):

$$
\ln \left(N_{X(t)}\right)=\ln \left(N_{X(0)}\right)+D_{X} t
$$

where $N_{x(0)}$ is the abundance of variable $x$ at $0 \mathrm{~d}, N_{x(t)}$ is the abundance of $x$ at $t \mathrm{~d}, D_{x}$ is the decay rate of $x$, and $t$ is the elapsed time (d) after the storage experiments began. Data for statistical analyses were natural log transformed. Regression analyses and $t$-tests were carried out using the SPSS software for Windows (Version 12.0, 2003). Error propagation was used to determine the SD of the means of the BA and VA for each time point, and it was expressed as a percentage of the initial value (Sachs 1984).

\section{RESULTS AND DISCUSSION}

\section{Theoretical considerations}

First, in order to determine a way for estimating the FVIB $_{\text {i }}$ (i.e. the FVIB at the time of storage) from longterm stored samples, a bacterial community was hypothetically considered to be composed of 2 groups in terms of decay as follows:

$$
\begin{aligned}
\mathrm{BA}_{\mathrm{i}} & =\mathrm{VIBA}_{\mathrm{i}}+\mathrm{OBA}_{\mathrm{i}} \\
\mathrm{BA}_{\mathrm{f}} & =\mathrm{VIBA}_{\mathrm{f}}+\mathrm{OBA}_{\mathrm{f}}
\end{aligned}
$$

where BA is total abundance of bacteria, which is the sum of the VIBA and other bacteria (OBA, including bacteria that are not visibly infected or non-infected, i.e. $\mathrm{OBA}=\mathrm{BA}-\mathrm{VIBA}$ ). Subscripts ' $\mathrm{i}$ ' and ' $\mathrm{f}$ ' represent the sampling times at the initial and the final storage times, respectively. Assuming an exponential decay relationship for the bacterial numbers during the storage of preserved samples (Turley \& Hughes 1992) yields the following:

$$
\begin{aligned}
\mathrm{OBA}_{\mathrm{f}} & =\mathrm{OBA}_{\mathrm{i}} \times \mathrm{e}^{\text {DOBA } \times t} \\
\mathrm{VIBA}_{\mathrm{f}} & =\mathrm{VIBA}_{\mathrm{i}} \times \mathrm{e}^{\text {DVIBA } \times t}
\end{aligned}
$$



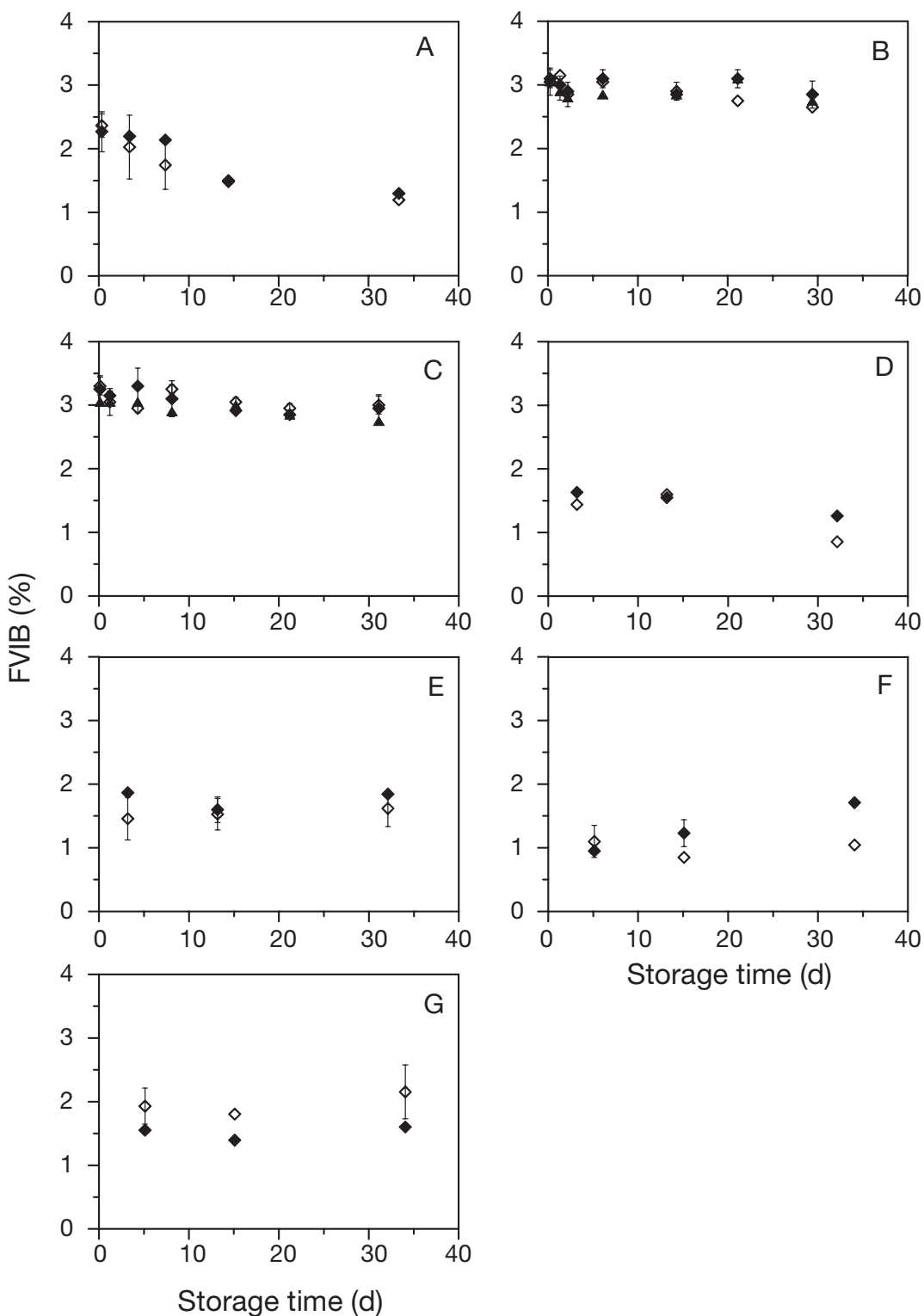

Fig. 1. Frequency of visibly infected bacteria (FVIB) in preserved seawater samples with $2 \%$ glutaraldehyde (final conc.) obtained from depths of (A) $0 \mathrm{~m}$ at Stn JJ, (B) $0 \mathrm{~m}$ at Stn JA, (C) $0 \mathrm{~m}$ at Stn S, (D) $5 \mathrm{~m}$ and (E) $170 \mathrm{~m}$ at Stn B1, and (F) $5 \mathrm{~m}$ and (G) $500 \mathrm{~m}$ at Stn B2. Storage temperatures: $4^{\circ} \mathrm{C}(\diamond),-20^{\circ} \mathrm{C}(\diamond)$, and $-80^{\circ} \mathrm{C}(\boldsymbol{\Delta})$. When bars are not shown, 1 SD is less than size of the symbol $(n=3$ for panels $\mathrm{B}$ and $\mathrm{C}$, and $\mathrm{n}=2$ for others)

where $\mathrm{D}_{\mathrm{OBA}}$ and $\mathrm{D}_{\mathrm{VIBA}}$ are defined as the decay constants for the OBA and VIBA, respectively, with storage time $(t)$.

The values of BA and FVIB at the end of storage $\left(\mathrm{BA}_{\mathrm{f}}\right.$ and $\mathrm{FVIB}_{\mathrm{f}}$, respectively) enable us to calculate the $\mathrm{OBA}_{\mathrm{f}}$ (Eq. 3). According to Eq. (4), OBA $\mathrm{i}$ can be calculated if $\mathrm{D}_{\mathrm{OBA}}$ can be measured experimentally. However, direct determination of the $\mathrm{D}_{\mathrm{OBA}}$ in natural seawater seems almost impossible with currently available techniques. Alternatively, it may be assumed that $\mathrm{D}_{\mathrm{OBA}}$ is approximately equal to the decay constant of total bacteria $\left(D_{\mathrm{BA}}\right)$, since OBA usually comprises a large fraction (ca. 97.5\%, Binder 1999) of the total bacteria. In fact, the average $\mathrm{D}_{\mathrm{OBA}}$ of our preserved samples was calculated to be $98.2 \%$ of $\mathrm{D}_{\mathrm{BA}}$ (data not shown). In our numerical simulation, in which the $\mathrm{BA}$ and $\mathrm{D}_{\mathrm{BA}}$ are typically considered as $10^{6}$ cells $\mathrm{ml}^{-1}$ and $-0.01 \mathrm{~d}^{-1}$ (corresponding to the mean $D_{\mathrm{BA}}$ value of our samples), respectively, the OBA was 95 to $99.7 \%$ of the total bacteria (i.e. based on FVIB values of 0.3 to $5 \%$ reported in the literature; Wommack \& Colwell 2000 ), and the ratio of $D_{\text {VIBA }}$ to $D_{\mathrm{OBA}}$ mostly varied from 0.1 to 5 in our stored samples; the differences between the $\mathrm{D}_{\mathrm{BA}}$ and $\mathrm{D}_{\mathrm{OBA}}$ were found to be less than $11 \%$ (data not shown). Thus, the $\mathrm{OBA}_{i}$ can be estimated from the $\mathrm{OBA}_{\mathrm{f}}$ and $\mathrm{D}_{\mathrm{BA}}$ (Eq. 4); subsequently the $\mathrm{VIBA}_{i}$ can be calculated since the $\mathrm{BA}_{\mathrm{i}}$ can be measured experimentally (Eq. 2). Thus, the $\mathrm{FVIB}_{i}$ can be calculated as a ratio of the $\mathrm{VIBA}_{\mathrm{i}}$ to $\mathrm{BA}_{\mathrm{i}}$.

\section{Application to preserved seawater samples}

For the coastal samples, the $\mathrm{FVIB}_{\mathrm{i}}$ (2.3 to $3.3 \%$ ) either decreased or varied slightly with storage time (Fig. 1A-C). As expected, the variations in the FVIB with storage time were due to the discrepancy between the $\mathrm{D}_{\mathrm{VIBA}}$ and $\mathrm{D}_{\mathrm{OBA}}$ values. For the coastal samples, $\mathrm{D}_{\mathrm{VIBA}}(-0.006$ to $-0.014 \mathrm{~d}^{-1}$ ) was 1.2 - to 7.2 -fold higher than $\mathrm{D}_{\mathrm{OBA}}$ over the entire storage period (data not shown). Thus, it is apparent that the BMVL estimated using the $\mathrm{FVIB}_{\mathrm{f}}$ value (i.e. $\mathrm{BMVL}_{\mathrm{f}}$ ) could be erroneous (Table 1). In our samples, the $\mathrm{BMVL}_{\mathrm{f}}$ calculated using the $\mathrm{FVIB}_{\mathrm{f}}$ at the end of ca. 1 mo of storage could introduce an error (up to $54.5 \%$ ) compared to the $\mathrm{BMVL}_{\mathrm{i}}$ (Table 1).

To estimate the $\mathrm{FVIB}_{\mathrm{i}}$ on the basis of our theoretical considerations, the values of $\mathrm{BA}_{\mathrm{i}}, \mathrm{BA}_{\mathrm{f}}, \mathrm{D}_{\mathrm{BA}}$, and $\mathrm{FVIB}_{\mathrm{f}}$ should be determined from the storage experiments. Interestingly, a good correspondence between the estimated $\mathrm{FVIB}_{\mathrm{i}}$ and measured $\mathrm{FVIB}_{\mathrm{i}}$ was found (the slope 
Table 1. Bacterial mortality due to viral lysis (BMVL, values in \%). Initial and final BMVL (BMVL $\mathrm{L}_{\mathrm{i}}$ and $\left.\mathrm{BMVL}_{\mathrm{f}}\right) \mathrm{Were} \mathrm{calculated}$ using the initial and final frequency of visibly infected bacteria, $\mathrm{FVIB}_{\mathrm{i}}$ and $\mathrm{FVIB}_{\mathrm{f}}$, respectively. Estimated $\mathrm{BMVL}_{\mathrm{i}}$ was obtained using the theoretical approach for preserved seawater samples stored for 15 and $30 \mathrm{~d}$. Values are represented as mean \pm SD (for Stns JA and $S_{i} n=3$ ) or a range (for others; $n=2$ ). For the offshore (Stns B1 and B2) samples, the first time point of sampling was at 3 to $5 \mathrm{~d}$ of storage

\begin{tabular}{|c|c|c|c|c|c|c|c|}
\hline \multirow[t]{2}{*}{ Stn } & \multirow{2}{*}{$\begin{array}{l}\text { Depth } \\
\text { (m) }\end{array}$} & \multirow{2}{*}{$\begin{array}{c}\text { Storage } \\
\text { temp. }\left({ }^{\circ} \mathrm{C}\right)\end{array}$} & \multirow{2}{*}{$\begin{array}{l}\text { Measured } \\
\text { BMVL }_{\mathrm{i}}\end{array}$} & \multicolumn{2}{|c|}{30 d-stored } & \multicolumn{2}{|c|}{$15 \mathrm{~d}$-stored } \\
\hline & & & & $\mathrm{BMVL}_{\mathrm{f}}$ & Estimated $\mathrm{BMVL}_{\mathrm{i}}$ & $\mathrm{BMVL}_{\mathrm{f}}$ & Estimated BMVL \\
\hline \multirow[t]{3}{*}{ JA } & 0 & -80 & $28.3 \pm 0.5$ & $25.1 \pm 0.5$ & $30.9 \pm 1.2$ & $26.2 \pm 0.4$ & $27.0 \pm 0.4$ \\
\hline & & -20 & $29.2 \pm 1.0$ & $26.2 \pm 1.2$ & $28.1 \pm 1.1$ & $26.2 \pm 0.3$ & $32.1 \pm 0.6$ \\
\hline & & 4 & $28.6 \pm 1.5$ & $24.0 \pm 0.5$ & $26.8 \pm 0.7$ & $26.8 \pm 0.4$ & $25.5 \pm 0.7$ \\
\hline \multirow[t]{3}{*}{$\mathrm{S}$} & 0 & -80 & $28.6 \pm 0.3$ & $25.7 \pm 0.4$ & $27.5 \pm 0.8$ & $28.0 \pm 0.2$ & $29.3 \pm 0.5$ \\
\hline & & -20 & $31.0 \pm 1.5$ & $27.4 \pm 1.3$ & $29.2 \pm 0.9$ & $27.0 \pm 0.5$ & $30.9 \pm 0.5$ \\
\hline & & 4 & $31.6 \pm 1.0$ & $28.0 \pm 0.8$ & $32.2 \pm 1.2$ & $28.6 \pm 0.3$ & $30.2 \pm 0.5$ \\
\hline \multirow[t]{2}{*}{ JJ } & 0 & -20 & $18.9-20.7$ & $10.2-10.6$ & $17.6-18.0$ & $11.8-12.4$ & $18.2-18.8$ \\
\hline & & 4 & $19.6-22.2$ & $8.7-10.3$ & $23.8-25.8$ & $11.4-12.8$ & $14.6-17.8$ \\
\hline \multirow[t]{2}{*}{ B1 } & 5 & -20 & $13.4-13.6$ & $9.5-10.7$ & $12.5-13.7$ & $12.5-12.9$ & $12.0-12.4$ \\
\hline & & 4 & $10.9-12.5$ & $5.7-7.5$ & $14.8-17.0$ & $12.4-13.8$ & $12.7-14.1$ \\
\hline \multirow[t]{2}{*}{ B1 } & 170 & -20 & $15.1-16.5$ & $14.8-16.2$ & $12.5-15.1$ & $11.9-14.5$ & $9.6-12.0$ \\
\hline & & 4 & $9.8-14.0$ & $11.6-15.2$ & $11.1-14.5$ & $11.0-14.0$ & $10.3-13.3$ \\
\hline \multirow[t]{2}{*}{ B2 } & 5 & -20 & $6.7-8.1$ & $13.7-14.7$ & $4.6-5.6$ & $8.5-11.1$ & $6.6-9.0$ \\
\hline & & 4 & $7.2-10.2$ & $7.5-8.9$ & $9.7-11.1$ & $5.5-7.5$ & $6.9-9.1$ \\
\hline \multirow[t]{2}{*}{ B2 } & 500 & -20 & $12.2-13.2$ & $12.6-13.8$ & $15.4-16.6$ & $10.9-11.7$ & $7.8-8.6$ \\
\hline & & 4 & $14.5-18.3$ & $15.7-21.5$ & $10.7-15.7$ & $14.2-16.0$ & $12.1-13.7$ \\
\hline
\end{tabular}

and intercept of the regression line were not statistically different $[\mathrm{p}>0.05, t$-test] from 1 and 0 , respectively; data not shown), indicating that the $\mathrm{BA}_{\mathrm{i}}, \mathrm{BA}_{\mathrm{f}}$ $\mathrm{D}_{\mathrm{BA}}$, and $\mathrm{FVIB}_{\mathrm{f}}$ can be used to reliably predict the $\mathrm{FVIB}_{\mathrm{i}}$. The estimated $\mathrm{FVIB}_{\mathrm{i}}$ was $99.7 \pm 7.7 \%$ (mean \pm $\mathrm{SD}, \mathrm{n}=8 ; 90.9$ to $114.3 \%$ ) of the measured $\mathrm{FVIB}_{\mathrm{i}}$ for the preserved coastal samples. Accordingly, the BMVL values based on the estimated $\mathrm{FVIB}_{i}$ were closer to the $\mathrm{BMVL}_{\mathrm{i}}\left(89.9\right.$ to $118.7 \%$ of the $\mathrm{BMVL}_{\mathrm{i}}$ ) than to the BMVL obtained using the $\mathrm{FVIB}_{\mathrm{f}}(45.5$ to $89.9 \%$ of the $\mathrm{BMVL}_{\mathrm{i}}$, Table 1). Further, we tested if the abovementioned theoretical consideration could also be applied to estimating the $\mathrm{FVIB}_{\mathrm{i}}$ in coastal samples stored for $2 \mathrm{wk}$. The BMVL values calculated with the estimated $\mathrm{FVIB}_{i}$ were comparable to those obtained with the measured FVIB (Table 1).

For the offshore samples, the $\mathrm{FVIB}_{\mathrm{i}}$ at the time of preservation could not be measured due to the unavailability of an ultracentrifuge on the research vessel. Inevitably, the first time point to measure the FVIB for the offshore seawaters was 3 to $5 \mathrm{~d}$ after the start of the storage experiments (Fig. 1D-G). Even in such a case, $\mathrm{FVIB}_{i}$ can be mathematically estimated using the values of $\mathrm{BA}_{\mathrm{i}}, \mathrm{BA}_{\mathrm{f}}, \mathrm{D}_{\mathrm{BA}}$, and $\mathrm{FVIB}_{\mathrm{f}}$ based on our theoretical considerations, although verification of the calculation is not possible due to a lack of measured $\mathrm{FVIB}_{\mathrm{i}}$ data. Interestingly, the estimated $\mathrm{FVIB}_{\mathrm{i}}$ values were very comparable to the measured FVIB values at 3 to $5 \mathrm{~d}$ after the start of the experiments (measured FVIB 3 -5di Fig. 2). Similarly, comparable values between the measured $\mathrm{FVIB}_{i}$ values and the FVIB values obtained from 3.4 to $6.1 \mathrm{~d}$ stored coastal samples (83.8 to $101.5 \%$ of the measured $\mathrm{FVIB}_{\mathrm{i}}$; data not shown) were found. Furthermore, the 2 regression lines for the coastal and offshore samples (Fig. 2) were statistically identical ( $p>0.05, t$-test; data not shown):

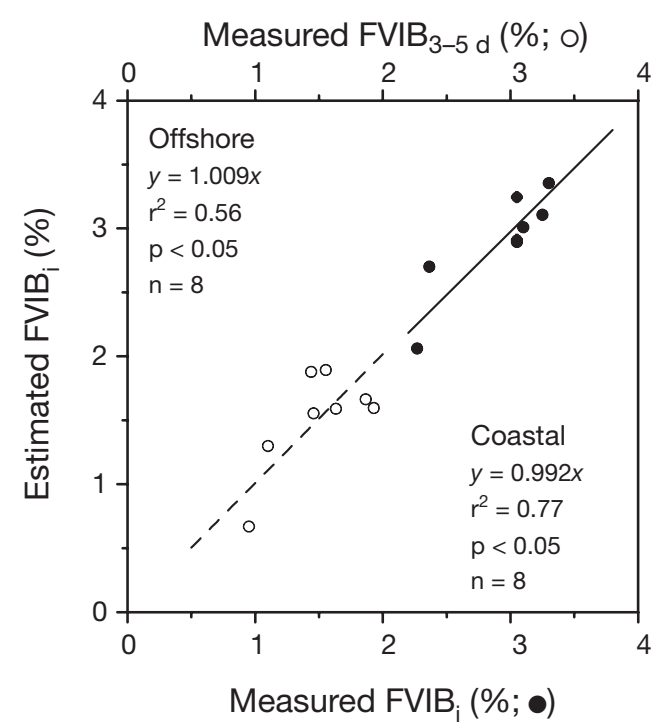

Fig. 2. Relationship between the frequency of visibly infected bacteria (FVIB) measured at the start of the storage experiments $\left(\mathrm{FVIB}_{\mathrm{i}}\right)$ and estimated $\mathrm{FVIB}_{\mathrm{i}}$ from 1 mo-preserved seawater samples. Measured $\mathrm{FVIB}_{3-5 \mathrm{~d}}$ represents FVIB determined at 3 to $5 \mathrm{~d}$ after the start of the storage experiments. Regression lines for coastal $(\bullet$, solid line) and offshore $(\mathrm{O}$, dashed line) samples 

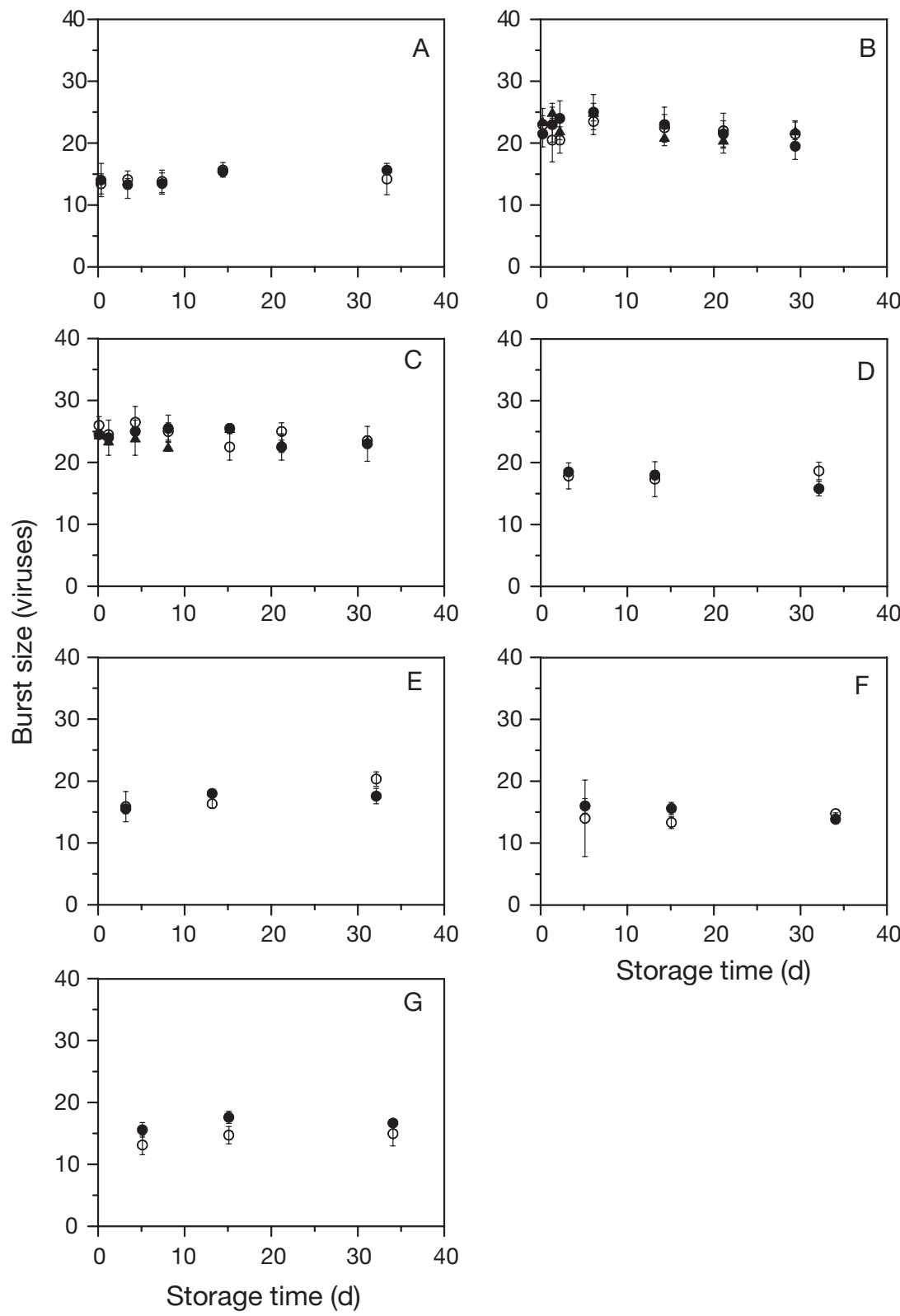

Fig. 3. Burst sizes in preserved seawater samples obtained from depths of (A) $0 \mathrm{~m}$ at Stn JJ, (B) $0 \mathrm{~m}$ at Stn JA, (C) $0 \mathrm{~m}$ at Stn S, (D) $5 \mathrm{~m}$ and (E) $170 \mathrm{~m}$ at Stn B1, and (F) $5 \mathrm{~m}$ and (G) $500 \mathrm{~m}$ at Stn B2. Other details as in Fig. 1

the intercept of the regression line for each sample was not different from 0 ( $\mathrm{p}>0.05, t$-test; data not shown), and hence, the ratios of the estimated $\mathrm{FVIB}_{\mathrm{i}}$ to the measured $\mathrm{FVIB}_{\mathrm{i}}$ (for the coastal samples) or the estimated $\mathrm{FVIB}_{\mathrm{i}}$ to the measured $\mathrm{FVIB}_{3-5 \mathrm{~d}}$ (for the offshore samples) were calculated as the slopes by using linear regressions (forced zero intercept; Fig. 2). The results revealed that the slope of the regression for each sample was not statistically different from 1 ( $\mathrm{p}>0.05, t$ test; data not shown). These circumstances possibly suggested that our theoretical considerations are applicable to preserved offshore samples stored for ca. 1 mo.

Effects of storage on the burst size in preserved seawater seemed to be negligible in our samples; burst sizes were 13 to 14 and 22 to 26 at the beginning of the storage experiments for the coastal samples collected in January 2005 and August 2007, respectively (Fig. 3A-C). The slopes of regression lines for the data of burst size along with storage time were not different from $0(\mathrm{p}>0.11, t$-test; data not shown), indicating that the burst sizes remained statistically constant over the storage period. Likewise, the burst sizes for the preserved offshore samples were statistically unchanged over the storage period ( $p>0.08, t$-test; Fig. 3D-G). The small variation in burst sizes over the storage period might suggest that the factors causing the decreases in VA (e.g. degradations due to extracellular enzymes and/or repeated freezing and thawing) damage the viruses within bacteria to a lower extent than the bulk-phase viruses in preserved seawaters.

Effects of storage on the BA and VA were less in the samples that were flash frozen in liquid nitrogen and subsequently stored at $-80^{\circ} \mathrm{C}$ than in the samples stored at 4 or $-20^{\circ} \mathrm{C}$ (Fig. 4B,C). The slope of the regression line for BA (i.e. decay rate) was statistically 1.7 - to 1.8 -fold less ( $p<0.05, t$ test; data not shown) for the preserved coastal sample stored at $-80^{\circ} \mathrm{C}[\ln ($ percent remaining) $=-0.006 \mathrm{~d}+4.577$ (where $\mathrm{d}$ represents storage days, $\mathrm{r}^{2}=$ $0.52, \mathrm{n}=21$ ); Fig. $4 \mathrm{C}$ ] than for the preserved coastal samples stored at 4 or $-20^{\circ} \mathrm{C}$. Consistent with this observation, viral decays were significantly slow in the preserved coastal samples stored at $-80^{\circ} \mathrm{C}$ ( $\mathrm{p}<0.05, t$-test; data not shown) and were approximated with the following equations: $\ln$ (percent remaining $)=-0.003 \mathrm{~d}+4.585\left(\mathrm{r}^{2}=0.49, \mathrm{n}=21\right.$; Fig. 4B $)$ and $\ln$ (percent remaining $)=-0.010 \mathrm{~d}+4.611\left(\mathrm{r}^{2}=0.75\right.$, $\mathrm{n}=21 ;$ Fig. 4 C). There were no statistical differences ( $\mathrm{p}$ $>0.05$ ) between the regression lines for the BA in the preserved samples stored at 4 and $-20^{\circ} \mathrm{C}$ (Fig. 4). In addition, there were no statistical differences $(p>0.05)$ between the regression lines for the VA in the preserved samples stored at 4 and $-20^{\circ} \mathrm{C}$ (Fig. 4). Our 

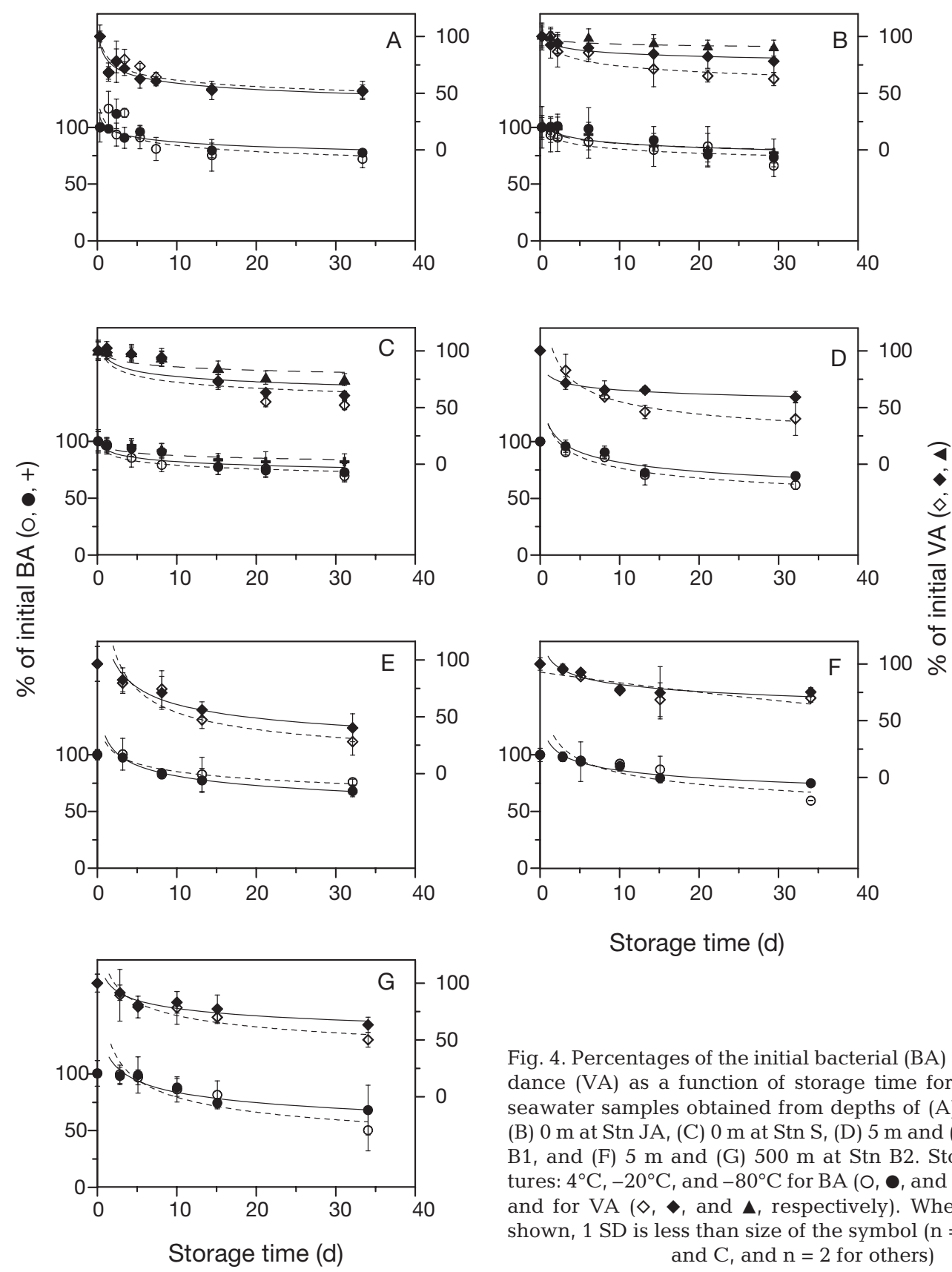

Fig. 4. Percentages of the initial bacterial (BA) and viral abundance (VA) as a function of storage time for the preserved seawater samples obtained from depths of (A) $0 \mathrm{~m}$ at Stn JJ, (B) $0 \mathrm{~m}$ at Stn JA, (C) $0 \mathrm{~m}$ at Stn S, (D) $5 \mathrm{~m}$ and (E) $170 \mathrm{~m}$ at Stn $\mathrm{B} 1$, and (F) $5 \mathrm{~m}$ and (G) $500 \mathrm{~m}$ at Stn B2. Storage temperatures: $4^{\circ} \mathrm{C},-20^{\circ} \mathrm{C}$, and $-80^{\circ} \mathrm{C}$ for $\mathrm{BA}(\mathrm{O}, \bullet$, and + , respectively) and for VA $(\diamond, \diamond$, and $\boldsymbol{\Delta}$, respectively). When bars are not shown, $1 \mathrm{SD}$ is less than size of the symbol $(\mathrm{n}=3$ for panels $\mathrm{B}$ and $\mathrm{C}$, and $\mathrm{n}=2$ for others)

results revealed that preserving bacteria and viruses in seawaters by flash freezing with liquid nitrogen and storing at $-80^{\circ} \mathrm{C}$ is the preferred method for preventing rapid decreases in the $\mathrm{BA}$ and VA due to long-term storage. However, even when the recommended storage method is employed, our theoretical consideration would still facilitate the estimation of a reliable $\mathrm{FVIB}_{\mathrm{i}}$ value (Table 1).

Significant decreases in the BA and VA were observed in the offshore seawater samples preserved with $2 \%$ glutaraldehyde (final conc.) and stored at 4

and $-20^{\circ} \mathrm{C}$ after ca. 1 mo of storage (Fig. 4). The BA decreases were 25 to $32 \%$ at the end of storage at $-20^{\circ} \mathrm{C}$ (Fig. 4). The $D_{B A}$ values ranged from -0.007 to $-0.012 \mathrm{~d}^{-1}$ during the entire storage experiment. Gundersen et al. (1996) obtained a similar result; they observed that the decrease in the BA was ca. $34 \%$ within $30 \mathrm{~d}$ of storing samples obtained from a depth of $100 \mathrm{~m}$ offshore of the Sargasso Sea that were preserved with $2.5 \%$ glutaraldehyde (final conc.), rapidly frozen, and stored at $-20^{\circ} \mathrm{C}$. They showed that the proteolytic breakdown of the cells might be a cause for 
the BA decrease in the glutaraldehyde-preserved samples (Gundersen et al. 1996). Additionally, since freezing and thawing treatments might increase cell lyses (Fuhrman et al. 1988, Kawai et al. 2002) in 3 out of 4 of our preserved offshore samples, repeated freezing and thawing resulted in $\mathrm{D}_{\mathrm{BA}}$ values ranging from -0.014 to $-0.019 \mathrm{~d}^{-1}$, which were significantly higher than those obtained for the samples stored at $-20^{\circ} \mathrm{C}$ and not subjected to freeze-thawing cycles ( $p<0.05$; data not shown).

The decay rates of VA $\left(\mathrm{D}_{\mathrm{VA}}\right)$ were -0.003 to $-0.016 \mathrm{~d}^{-1}$ in our samples stored at $-20^{\circ} \mathrm{C}$ over the entire storage period (Fig. 4). Except for the surface sample obtained from Stn B2, the $\mathrm{D}_{\mathrm{VA}}$ values were 2.0to 3.1-fold higher than the $\mathrm{D}_{\mathrm{BA}}$ values, indicating that viruses might undergo decay more easily than bacteria in the glutaraldehyde-preserved seawater samples stored at $-20^{\circ} \mathrm{C}$. Likewise, viral decay $(-0.013$ to -0.021 $\left.\mathrm{d}^{-1}\right)$ was generally higher than bacterial decay $(-0.009$ to $\left.-0.015 \mathrm{~d}^{-1}\right)$ in the preserved and stored samples at $4^{\circ} \mathrm{C}$ (data not shown). However, the $\mathrm{D}_{\mathrm{VA}}$ was not significantly different between the preserved samples stored at $4{ }^{\circ} \mathrm{C}$ and those stored at $-20^{\circ} \mathrm{C}(\mathrm{p}>0.05)$. As observed with regard to the BA in our samples, repeated cycles of freeze-thawing significantly increased (2-fold) the $\mathrm{D}_{\mathrm{VA}}$ of these samples, such that it was higher than that of the samples stored at $-20^{\circ} \mathrm{C}$ and not subjected to freeze-thawing cycles $(\mathrm{p}<0.05$; data not shown).

A few other studies have reported decreases in the VA (i.e. a 66 to $80 \%$ decrease in the initial VA) of preserved samples following storage of the water samples at 4 or $-20^{\circ} \mathrm{C}$ for 30 to $40 \mathrm{~d}$ (Steward et al. 1996, Xenopoulos \& Bird 1997, Marie et al. 1999, Brussaard 2004). In the present study, the VA decreases ranged from 30.0 to $68.6 \%$ at the end of the storage at $-20^{\circ} \mathrm{C}$ (Fig. 4), but these decreases were rather low compared to those reported by other studies. In addition, the initial $\mathrm{D}_{\mathrm{VA}}\left(-0.13\right.$ to $\left.-0.07 \mathrm{~d}^{-1}\right)$ of the coastal samples stored at $4^{\circ} \mathrm{C}$ over the first $2 \mathrm{~d}$ of storage (Fig. 4A-C) were less than those reported for a coastal seawater sample stored under identical conditions $\left(-0.28 \mathrm{~d}^{-1}\right.$; Wen et al. 2004). This discrepancy among studies in terms of $\mathrm{D}_{\mathrm{VA}}$ might be explained by the differences in the physical and/or biological characteristics of each environment (e.g. aggregate formation, enzymatic activity, and viral assemblage composition; Marie et al. 1999, Brussaard 2004, Wen et al. 2004).

In summary, as reported by other studies, the BA and VA in 7 preserved seawater samples stored at $4,-20$, and $-80^{\circ} \mathrm{C}$ decreased with increasing storage time. The variation in the FVIB with long-term storage was inconsistent among different samples; the $\mathrm{FVIB}_{\mathrm{f}}$ values covered a wide range $\left(50.6\right.$ to $91.9 \%$ of the FVIB $_{i}$ and 59.3 to $179.8 \%$ of the FVIB $_{3-5 d}$ for the coastal and off- shore samples, respectively), indicating that the FVIB obtained from the long-term stored samples might introduce an error if used to estimate the BMVL at the time of preservation. Instead, the $\mathrm{FVIB}_{\mathrm{i}}$ can be well estimated using the $\mathrm{BA}_{\mathrm{i}}, \mathrm{D}_{\mathrm{BA}}, \mathrm{FVIB}_{\mathrm{f}}$, and $\mathrm{BA}_{\mathrm{f}}$. Therefore, it is recommended that the abovementioned variables be measured in order to reliably estimate the $\mathrm{FVIB}_{\mathrm{i}}$ for fixative-amended and frozen seawater samples subjected to long-term storage (e.g. 1 mo), in cases such as oceanic cruises, until techniques for the in situ determination of the FVIB improve.

Acknowledgements. We thank the captain and crews of the RV 'Tamyang' for their cooperation. We also acknowledge the technical support of I. Lee (electron microscopy), National Center for Inter-university Research Facilities, Seoul National University. This work was partly supported by the BK21 project of the Korean Government and by the Korea EAST-1 Program of the Ministry of Maritime Affairs and Fisheries.

\section{LITERATURE CITED}

Binder B (1999) Reconsidering the relationship between virally induced bacterial mortality and frequency of infected cells. Aquat Microb Ecol 18:207-215

Brussaard CPD (2004) Optimization of procedures for counting viruses by flow cytometry. Appl Environ Microbiol 70: 1506-1513

> Choi DH, Hwang CY, Cho BC (2003) Comparison of virusand bacterivory-induced bacterial mortality in the eutrophic Masan Bay, Korea. Aquat Microb Ecol 30: $117-125$

> Fuhrman JA, Comeau DE, Hagström Å, Chan AM (1988) Extraction from natural planktonic microorganisms of DNA suitable for molecular biological studies. Appl Environ Microbiol 54:1426-1429

Gundersen K, Bratbak G, Heldal M (1996) Factors influencing the loss of bacteria in preserved seawater samples. Mar Ecol Prog Ser 137:305-310

Hwang CY, Cho BC (2002) Uneven growth and different susceptibility to viruses among bacteria increase estimates of virus production in the East Sea based on TEM observation. Aquat Microb Ecol 27:211-218

Kawai M, Matsutera E, Kanda H, Yamaguchi N, Tani K, Nasu M (2002) 16S ribosomal DNA-based analysis of bacterial diversity in purified water used in pharmaceutical manufacturing processes by PCR and denaturing gradient gel electrophoresis. Appl Environ Microbiol 68: 699-704

Marie D, Brussaard CPD, Thyrhaug R, Bratbak G, Vaulot D (1999) Enumeration of marine viruses in culture and natural samples by flow cytometry. Appl Environ Microbiol 65:45-52

Noble RT, Fuhrman JA (1997) Virus decay and its causes in coastal waters. Appl Environ Microbiol 63:77-83

> Noble RT, Fuhrman JA (1998) Use of SYBR Green I for rapid epifluorescence counts of marine viruses and bacteria. Aquat Microb Ecol 14:113-118

Sachs L (1984) Statistical decision techniques. In: Applied statistics: a handbook of techniques, 2nd edn. Springer, New York, p 23-194

Steward GF, Smith DC, Azam F (1996) Abundance and pro- 
duction of bacteria and viruses in the Bering and Chukchi Seas. Mar Ecol Prog Ser 131:287-300

Suttle CA (1993) Enumeration and isolation of viruses. In: Kemp PF, Sherr BF, Sherr EB, Cole JJ (eds) Handbook of methods in aquatic microbial ecology. CRC Press, Boca Raton, FL, p 127-129

Suttle CA, Chen F (1992) Mechanisms and rates of decay of marine viruses in seawater. Appl Environ Microbiol 58: $3721-3729$

Turley CM, Hughes DJ (1992) Effects of storage on direct estimates of bacterial numbers of preserved seawater samples. Deep-Sea Res 39:375-394

Turley CM, Hughes DJ (1994) The effect of storage temperature on the enumeration of epifluorescence-detectable bacterial cells in preserved sea-water samples. J Mar Biol Assoc UK 74:259-262

Weinbauer MG (2004) Ecology of prokaryotic viruses. FEMS Microbiol Rev 28:127-181

Editorial responsibility: Jed Fuhrman,

Los Angeles, California, USA
Weinbauer MG, Fuks D, Peduzzi P (1993) Distribution of viruses and dissolved DNA along a coastal trophic gradient in the northern Adriatic Sea. Appl Environ Microbiol 59:4074-4082

Weinbauer MG, Winter C, Höfle M (2002) Reconsidering transmission electron microscopy based estimates of viral infection of bacterioplankton using conversion factors derived from natural communities. Aquat Microb Ecol 27: 103-110

Wen K, Ortmann AC, Suttle CA (2004) Accurate estimation of viral abundance by epifluorescence microscopy. Appl Environ Microbiol 70:3862-3867

Wommack KE, Colwell RR (2000) Virioplankton: viruses in aquatic ecosystems. Microbiol Mol Biol Rev 64:69-114

Xenopoulos MA, Bird DF (1997) Virus á la sauce YoPro: microwave-enhanced staining for counting viruses by epifluorescence microscopy. Limnol Oceanogr 42: $1648-1650$

Submitted: March 15, 2007; Accepted: July 1, 2008 Proofs received from author(s): September 8, 2008 